\title{
American Movies' "Closest Equivalent to Restoration Comedy"
}

\author{
By Oliver Tilley
}

Fall 2009 Issue of KINEMA

\section{"IT MAY BE AMERICAN MOVIES' CLOSEST EQUIVALENT TO RESTORATION COMEDY"}

(Pauline Kael on Bringing Up Baby)

I will attempt to ascertain the accuracy of Pauline Kael's comment. It is a difficult issue, demanding a telescoping of two distinctive cultures, nations and media as well as an exploration of the concept of genre and intertextuality. In many ways Kael's assertion - written, as she herself attests 'hurriedly', being 'frequently dependent on [her] old, spotty memories'(1) - is superficial and breaks down after analysis. Her comparison is flawed in its assumptions that genres can contain such diverse works as they denote, over a fifty-year period on the one hand and a 10 year period on the other; while the idea that these genres can then be parallelled with each other is yet further problematic. Despite this, Kael's perhaps unthinking observation proves a worthwhile area to explore and reach beyond the surface qualities of tone and style on which she seems to base her assessment.

Kael, in her conversation with Ann Geracimos in 1969 concerning the 'Woman Reading', discusses how much she loves reading, how it is her 'favourite' pastime and how she could 'live without movies much more easily than [she] could live without books ${ }^{\prime(2)}$. During her conversation with Geracimos, Kael details a large variety of books, ranging from Nabokov to Synge, which she had read or which she had found compelling, with, significantly, no mention of Restoration Comedy. It is still possible that she had deeply explored the genre and simply not thought to mention her interest during this interview, but it offers the provocative suggestion that she has never read, and only cursorily seen, any of the plays. It is an extensive genre because it traditionally groups together material from around the years 1660 to 1700 (the era A History of Restoration Drama, 1660 - 1700 pegs off as the Restoration Drama epoch) or, to be more exact, 1660 to 1714, the period Deborah Payne Fisk delineates in her preface to The Cambridge Companion to English Restoration Theatre. Fisk accepts that some historians point to 1688 and the Glorious Revolution as the natural cut-off point for Restoration Comedy, as the restored monarch was by then deceased; but, like Brian Corman, she uses the 1688 period as a hinge, to differentiate between early 'Carolean' Restoration Drama and later 'post-Carolean' Restoration Drama. Corman describes the development of the genre in those fifty years in this way:

The prevailing change was one away from the social values that inform so much of Carolean comedy in favour of moral values of a more traditional and timeless sort, values shared in common by many pre-Restoration and post-Carolean comedies. The major casualty is the rake. ${ }^{(3)}$

Corman sees the Carolean era of Restoration Comedy as a period of indecency characterised by the unforgiving satire of Etherege and Wycherley, which segues into a more sentimental and morally aware trend. He refers to Cibber, Vanbrugh, Farquhar and Congreve as the main exponents of this more blunted comedy and there is a move towards narratives of resolution at odds with the bleak outlook of, for example, Wycherley. Such a softening is predictable given that the liberation of the years immediately following Charles II's Restoration would have dissipated by then. Moreover, there was a significant shift in the national consciousness against the excesses of Charles and James's reigns towards the more measured accountability of William of Orange, a shift expressed by Jeremy Collier in his A Short View of the Immorality, and Profaneness of the English Stage published in 1698 and summing-up such currents of thought. However, this change is over-emphasised and though Farquhar and Congreve evince some concessions to a more morally conscious audience, the outrageous spirit of Carolean comedy is still dominant. The Restoration Comedy genre is full of problems of definition and some works, though routinely placed within it, stretch the limits of genre.

Similar problems arise in attempting to group together Screwball comedies under one banner. The name itself was coined by a reviewer discussing My Man Godfrey (1936) and is now used to yoke together films from the supposed progenitor It Happened One Night (1934) to, conventionally, The Palm Beach Story (1942). There remains a lack of consensus however, with one critic, Stanley Cavell, refusing even to use 
the taxonomy 'Screwball Comedy', preferring 'Comedies of Remarriage' in his discussion of seven films which span the 'Screwball Cycle'. Cavell's inclusion of Adam's Rib (1949) in his discussion also increases the breadth of the cycle. There appears to be no agreement as to which films can be termed Screwball Comedies: online encyclopaedias throw in other unexpected films, such as Lubitsch's To Be or Not to Be (1942) in Wikipedia (en.wikipedia.org), Sturges's tragicomic Sullivan's Travels (1941) in The Internet Movie Database (www.imdb.com) or the Marx Brothers' A Night at the Opera (1935) in The All Movie Guide (www.allmovie.com).

However, there is some consensus regarding the common themes of these films: they often contain remarriage or courtship narratives concerning upper class figures refracted through a 'screwball' or 'screwy' style, variously described as 'madcap', 'lunatic' or, as Kael writes while discussing The Miracle of Morgan's Creek (1944) 'surreal-slapstick-satire-conniption-fit comedy'(4). Carol Lombard (referred to by the mid 1930s as 'the Duse of daffy comedy') and Cary Grant are the most prolific male and female leads throughout the cycle and it is their off-the-wall zaniness, their warped delivery and use of physical comedy, which made them such ideal Screwball icons. Duane Byrge and Robert Milton Miller in The Screwball Comedy Films have rightly emphasised the importance of Broadway and the silent-era comedies in shaping Screwball, not least because many of the film's scripts were re-workings of Broadway plays (for example, The Philadelphia Story (1940) or Twentieth Century (1934)) and many Screwball directors began their careers as silent film directors (Frank Capra in particular). It is the slapstick comedy of Chaplin which reverberates throughout Sturges's work (Sturges was an avowed slapstick enthusiast and repeatedly used it in his films); while the staginess and the artfully crafted scripts of most of the films is evidence of their Broadway roots.

Historically, Screwball Comedy is far removed from the conditions confronting Restoration Dramatists. Far from a liberation from censorship and a happy rebalancing of the socio-political climate, Screwball Comedy sprang from the Great Depression, just as Roosevelt's New Deal kicked in without yet yielding any results; while the cycle's first film marks the introduction of the Production Code, a prohibition of all allusions to what the Production Code Administration deemed indecent. Certainly, these two factors make the contexts of composition seem in many ways the reverse of each other. Where Restoration Comedy was produced for an elite of playgoers, Screwball Comedy functioned as something of an escapist fantasy for the masses (a purpose which filmmaker John L. Sullivan comes to appreciate in Sullivan's Travels), a key element of an industry which, even at the height of the Depression was making on average a film a day and sold 65 to 95 million tickets in 1932. Restoration Comedy sprang from a period of flourishing composition after the discontinuation of puritanical censorship laws, while Screwball Comedy saw the imposition of religious censorship. The threat of civil revolt was very real in 1930s America, while Restoration Britain had recently undergone revolution.

The conditions of viewing were also, in many ways, irreconcilable. Plays, for a Restoration audience, often functioned as social arenas where one could see and be seen by the beau monde (the fact that there were only two theatres for most of the period due to Killigrew's and Davenant's duopoly, would render the theatre yet more emphatically 'the place to be' for London's socialites) in which this social purpose was usually taken further and people caroused and even picked fights in the pit and in the boxes. Sparkish gives an apposite account of this in The Country Wife (1675), where he reveals himself to be a typical play-goer of the period:

'Gad, I go to a play as to a country treat, I carry my own wine to one, and my own wit to t'other, or else I'm sure I should not be merry at either. And the reason why we are so often louder than the players is because we think we speak more wit, and so become the poet's rivals in his audience. ${ }^{(5)}$

This 'rivalry' between 'poet' and 'audience' would make any simple, direct absorption of the material difficult and this speech may stem from Wycherley's frustration as his satirical, even pedagogic aims would be routinely undermined by the loss of the audience's attention. This is a far cry from the 'plush seats of darkened movie palaces' ${ }^{(6)}$ which characterised the American movie theatres of the 1930s, in which people were expected to sit and take notice in order to be absorbed into the movie and escape Depression-era reality. As Cavell puts it 'thirties comedies were fairytales for the depression'(7). Restoration Comedy offered escapism too, in that it provided only a selective slice of late seventeenth century life, neglecting to mention the Dutch Wars, the French Wars, the Exclusion Crisis, James II's Assassination Plot and the 
Glorious Revolution beyond anything more than an occasional allusion. Yet, the audiences of these comedies were still locked into reality, as they watched figures like themselves go about their business while they went about theirs.

Peter Holland has noted that 'to find out how the audience understood the play that they watched, a study of Thomas Betterton is as important as one of Dryden'(8). Certainly, as Joseph Roach asserts: 'actors and actresses became the first modern celebrities' ${ }^{\prime(9)}$. It is fair, then, to assume that Restoration Comedies throughout the period were shaped and received in terms of the actors and actresses who populated the 'Enchanted Isle', while one can easily see that playwrights would begin to pen characters and parts specifically for celebrated actors of the day. As Roach goes on to say 'in some instances the performers became so firmly associated with their roles that the plays with which they were thus affiliated could not be revived without them'(10): it seems that the star system of Hollywood was pre-empted in the seventeenth century.

There are surface similarities and differences concerning the style, tone and structure of each genre. Both are fast-paced, with scenes of multiple characters often creating a cacophony of overlapping cues, while the scripts are usually witty. In both there is a courtship narrative between innamorati, with supplemental plots and sub-plots in the more complicated Restoration Comedy, and a cast of peripheral though integral characters in Screwball comedy (typically 90 minutes long in contrast to the 180 minutes of Restoration comedy). They begin to differ more in their tone and narrative format however. Screwball Comedy is 'lunatic comedy' and thus contains madcap elements which, though present in Restoration Comedy, are not its main emphasis. Moreover, Restoration comedy has a dark, satirical edge which, though noticeable in some Screwball works (particularly Sturges's) is not predominant. Screwball Comedy uses conceits in its plots such as a court case in Adam's Rib, a newspaper story in both His Girl Friday and Nothing Sacred (1937) and a detective case in The Thin Man (1934). Restoration Comedy occasionally comes close, as in The Recruiting Officer, but generally it maintains a classic courtship narrative usually complicated by a forbidding parent, inheritance issues or money issues.

I asserted earlier that Restoration Comedies can be satirical and the abiding works of the Carolean period have a certain black comedy, sometimes introducing the danger of violence:

PINCHWIFE [to MRS PINCHWIFE]

Write as I bid you, or I will write whore with this penknife in your face.

$[\ldots]$

I will stab out those eyes that cause my mischief. ${ }^{(11)}$

This is where Pinchwife's obsessive jealousy regarding his wife erupts into the threat of violence. Much depends upon performance choices as to how this scene would appear: one could play Pinchwife as fierce and serious or as overcompensating with wild threats which are calculated only to scare. Mrs. Pinchwife's reaction is careless ('O Lord, O Lord, you are such a passionate man, bud!'(12) ) so one could suggest that she does not detect any real danger, but I believe that the play is ready to lurch into tragedy at this point; it is one of Wycherley's successes that he can create this ambiguity. Such black comedy is not found in Screwball, with the exception of the films of Preston Sturges, a director adept at creating a chiaroscuro of emotional effects. The Lady Eve (1942) for instance, takes its male lead Hopsy and takes him through a wrack of heartache, pratfalls and a vindictive revenge plot hatched by a vampiric Jean. Sturges is able to intermix bathos and pathos even in the most sincere moments, such as the hilltop scene in which Hopsy (Henry Fonda) declares his love for Jean / Eve (Barbara Stanwyck), only to be interrupted by a horse.

Sturges's use of slapstick is sophisticated: Stanwyck trips Fonda up in order that they meet, after throwing an apple at his head earlier on, illustrating her disruptive influence on Fonda, just as Hepburn's discarded olives which floor Grant in Bringing Up Baby signal her intrusive effect on him. Ed Sikov suggests that it is 'little wonder then they created comic characters who found themselves doing verbal and physical cartwheels as a way of dealing with frustrated passions' ${ }^{\prime 13)}$, referring to the effect of the Production Code. He suggests that slapstick was used as physical innuendo; but throughout the films it is rather a means for communicating thematic information or conveying the character's frustration, as in Holiday, where Grant's and Hepburn's acrobatics work as an ingenious expression of their fight against repression. The punch-up between Carol Lombard and Frederic March in Nothing Sacred serves as an example of Sikov's idea though, being a symbol of consummation used in order to bypass the Production Code Administration unscathed. 
Sikov also refers to 'verbal [...] cartwheels' and it is true that there is sexual tension bubbling beneath the heated confrontations between the leads, which occasionally reaches the surface, as in Hepburn's comment 'You really look handsome without your glasses on' in Bringing Up Baby. However, visual innuendo is far more prevalent and important in Screwball Comedy, with the crossing skis signalling Mr. and Mrs. Smith's reunited consummation at the end of Mr. E Mrs. Smith (1941), the horn-blowing and collapse of the 'walls of Jericho' in It Happened One Night, the clock-man following the clock-woman at the end of The Awful Truth (1937) which marks the reconciliation of Grant and Dunne, the zipping of Claudette Colbert's dress in The Palm Beach Story and Lombard's decisive cold shower towards the end of My Man Godfrey. The Hays Code provoked a certain inventiveness in filmmakers of the era and nowhere is this more the case than in the visual innuendo of Screwball.

Unless a director were to take a particularly brave choice, slapstick and visual innuendo are largely absent from Restoration Comedy, which rather glories in its freedom from censorship and indulges in explicitness whenever it can:

\section{SCANDAL}

I know Trapland has been a whoremaster, and loves a wench still. You never knew a whoremaster that was not an honest fellow.

TRAPLAND

Fie, Mr Scandal, you never knew -

SCANDAL

What don't I know? I know the buxom black widow in the Poultry - $£ 800$ a year jointure, and $£ 20,000$ in money. Ahah! Old Trap! ${ }^{(14)}$

Scandal seems to be as excited by the business of speaking indecently as the playwright: as Trapland attempts to temper Scandal, the latter delights in continuing saying 'what don't I know?'. The 'China scene' in The Country Wife is an example of brilliant innuendo writing, as Horner equates his adulterous services with the selling of China: 'I cannot make china for you all, but I will have a roll-wagon for you too another time.'(15) Elsewhere, Wycherley is more crude:

\section{SIR JASPER}

Wife! He is coming into you the back way.

\section{LADY FIDGET}

Let him come, and welcome, which way he will.

SIR JASPER

He'll catch you, and use you roughly, and be too strong for you. ${ }^{(16)}$

In its outrageousness this exchange manages to fuse the sense of glorified explicitness in post-Puritan writing with innuendo which seems to serve only as a means to accentuate its rudeness.

Stanley Cavell's references to the ideas of 'Old' and 'New' comedy are apposite, as they help articulate the nature of the comedy of Screwball and Restoration Comedy. It touches upon an argument raging between Thomas Shadwell and John Dryden during the 1660s in which the former expounds the merits of comedy based upon Jonsonian 'humours' as detailed in his preface to The Sullen Lovers (1668), while the latter promotes the idea of comedy based upon wit, as outlined in his An Essay of Dramatick Poesie (1668). Brian Corman summarises their views neatly:

True to his Jonsonian roots, Shadwell affirms the predominant theory of comedy since the Renaissance that it should achieve its moral end by rendering "Figures of Vice and Folly so ugly and detestable" that the audience will learn to "hate and despise them." Dryden counters that the moral function of comedy depends on the audience first being moved to pleasure and then analysing the source of that pleasure. To cause laughter at folly is to instruct by appealing to the lowest of human emotions. Wit comedy [...] teaches by positive example and is thus to be preferred over humours comedy with its negative examples. ${ }^{(17)}$

Corman goes on to suggest that Restoration dramatists used some of both theories, achieving a balanced if theoretically impure medium. Most Restoration Comedies have elements of wit and satire, it depends on which character one looks at in a given play: the fop figures are invariably laughed at and thus one is taught 
to avoid such behaviour, while the rake heroes are to be admired and, by extension of logic, emulated in their wit:

\author{
SPARKISH \\ DORILANT \\ A pox! I can hear no more, prithee. \\ HORNER \\ No, hear him out; let him tune his crowd a while. \\ HARCOURT \\ The worst music, the greatest preparation \\ SPARKISH \\ Nay, faith, I'll make you laugh. \\ $[\ldots]$ \\ HORNER \\ But the divel take me if thine be the sign of a jest. ${ }^{(18)}$
}

'Yes, but there was,' said I again, 'and it came out of France, and has been there a fortnight.'

This is a good example of the cacophonous quality of much of Restoration Comedy and one can imagine in performance the pace of each cue and the complicated oscillation of asides, conferring and open speech which the oblivious Sparkish cannot grasp. Sparkish is ganged up on by a trio of rakes, all of whom demonstrate a savvy and patronising self-assurance which he as the fop lacks, thus emphasising the qualities of both. This excerpt is gutted of a paragraph of Sparkish's speech which, when retained, gives an even clearer sense of his unwelcome garrulity and there does not seem to be any doubt that the audience should disdain his boorishness and admire the wit of Horner, Harcourt and Dorilant, who remain the heroes of the piece. It is not so simple of course: as Salgãdo asserts:

The Fop is laughed at not because he is trying to be something in itself contemptible, but rather because he is trying unsuccessfully to be something which, if he succeeded, would make him the play's hero. ${ }^{(19)}$

Thus the fop and rake-hero are not so far removed and it is rather the affected aspirations of the fop an audience is asked to ridicule in a Jonsonian fashion; as Sparkish desperately says later in the scene 'a wit to me is the greatest title in the world ${ }^{(20)}$. One is tempted to feel sorry for Sparkish at this point, as in others, rather than laugh at his bathos. Moreover, that Horner, perhaps the most paradigmatic rake in the Restoration Comedy canon, ends up unfulfilled in the play - 'I, alas, can't be [a husband] (21) - also helps subvert the idea that the rake is somehow superior.

If Restoration Comedy is a commixture of Jonsonian and Fletcherian elements of comedy, Screwball tips the balance towards a Fletcherian (witty) style. The type of excoriating satire so frequently found in Restoration Comedy (particularly in its Carolean incarnations) only barely registers in Screwball. The fop figure appears on the margins of each film if at all: Mischa Auer's 'Carlo' in My Man Godfrey provides one example - one struggles to think of another - and he appears only occasionally, to be dispatched violently and forgotten about at the close of the film. Some satire is reserved for the figure of the babbling matriarch, the 'dizzy old goat'(22) Angelica Bullock (Alice Brady) of My Man Godfrey or the predatory 'Princess Centimillia' (Mary Astor) in Palm Beach Story, both of whom recall figures such as Lady Wishfort in The Way of the World (1700). The Senex figure rarely features in Screwball Comedy either, with Holiday and (to a lesser extent) The Miracle of Morgan's Creek providing the only instances in the cycle. Instead, parents are usually silent adjuncts with no appreciable influence on the conduct of the innamorati, reflecting, perhaps, the greater independence and individuality of twentieth century Americans as much as a shift in the themes of the genre. One figure which does span some of the films is the 'anything for a quiet life', exasperated father used to emphasise his household's screwiness: Eugene Pallette plays the most representative example of this figure in both My Man Godfrey and The Lady Eve, while Walter Connolly has similar if briefer parts in It Happened One Night and Nothing Sacred (though he is not a father in the latter). It takes Pallette the entire film and a bankruptcy to control his household in My Man Godfrey and when he exclaims 'What this house needs is discipline'(23) amid a typical scene of pandemonium, one appreciates his impotence only more acutely.

Crucially, the innamorati of Screwball Comedy are quite different in style from those of Restoration Comedy. 
They will usually have been married or engaged (prompting Cavell's terminology 'Comedies of Remarriage'), which often gives their relationships a well-worn familiarity. The remarriage dynamic creeps into Colly Cibber's Love's Last Shift (1696) with Loveless's return from six months of debauchery away from his wife and into Wycherley's The Plain Dealer (1676) where Manly returns to England and attempts to reclaim Olivia only to find himself frustrated. Nevertheless, Restoration Comedy is usually exclusively focused upon fresh courtship, while Screwball covers old ground, making the lovers' eventual reunion seem inevitable. The most crucial distinction between the innamorati of both genres is the lack of a rake-hero in Screwball. There are some near examples, as in It Happened One Night and Clark Gable's rugged Peter Warne, who, though confident and admirable, remains too down-to-earth and ethical. Besides, the dynamic between the two lovers (or lovers-to-be) more often revolves around the assertive, 'screwy' qualities of the heroine in Screwball, which frequently requires a male straight-man to play off. The Katharine Hepburn / Cary Grant pairing in Bringing Up Baby (repeated in Holiday and The Philadelphia Story such was its success) is in many ways the archetypal Screwball lovers' dynamic, with the off-the-wall, unfathomable heroine drawing the bumbling ingénu man into a 'series of misadventures'(24).

David Huxley (Grant) illuminates this further when he says 'in moments of quiet I find myself strangely drawn to you; but there haven't been any quiet moments!' ${ }^{(25)}$, while he later provides an apt description of Susan's (Hepburn) mindset: 'Susan, you look at everything upside down' ${ }^{\text {(26) }}$. This 'upside down' way of looking at things is shared by Lombard in My Man Godfrey, in which the straight-laced Godfrey (William Powell) says to Irene (Lombard) 'I don't want to seem dull, but sometimes I don't follow you'(27); a sentiment voiced earlier by Mrs. Bullock when she says 'Irene is so peculiar, she cries when she's happy and shouts when she's winning' ${ }^{\prime 28)}$. It is this quality of unexpectedness which in many ways articulates the 'screwball' spirit: the 'nutty' household and the 'upside down' female lover are fundamental.

The straight-man sometimes appears in a different capacity, as the heroine's alternative lover, the rival to the central hero. The point about this stock character is that he is usually someone whom the heroine ought to marry in a sensible (that is, non-screwy) world but does not because of her ineffable attachment to the male lead. Ralph Bellamy's Daniel Leeson in The Awful Truth is the most complete example of this character, a part he would reprise in His Girl Friday, in which he is more clearly overshadowed by Grant's Machiavellian Burns. In the Awful Truth Bellamy is so wholesome as to be embarrassing, as he sings his piano tune and dances elaborately with Lucy (Irene Dunne) in front of Grant's wryly smiling Jerry. Bellamy is used as a tool by the female lead to generate jealousy and there should be no doubt in the audience's mind that the danger of their actually marrying is minimal.

Restoration Comedy does not offer an equivalent to the 'straight-man' (unless one counts, say, the Dottore figure of Major Oldfox in The Plain Dealer), but many of its female leads have similar qualities to Screwball heroines. Mirabell and Millamant in The Way of the World come very close to embodying the same breathless, chaotic dynamic as David and Susan in Bringing Up Baby:

\section{MIRABELL}

Think of you! To think of a whirlwind, though 'twere in a

whirlwind, were a case of more steady contemplation. ${ }^{(29)}$

The image of a whirlwind links with the 'upside down' Screwball outlook, and, though Mirabell is by no means the type of ingenuous straight-man to be found in Screwball, he is overwhelmed by the pugnacious Millamant:

MIRABELL

You are merry, madam, but I would persuade you for one moment to be serious.

MILLAMANT

What, with that face? No, if you keep your countenance, 'tis impossible I should hold mine. Well, after all, there is something very moving in a love-sick face - ha, ha, ha! - well I won't laugh; don't be peevish. Heigh-ho! Now I'll be melancholy, as melancholy as a watch-light [...] MIRABELL

Can you not find in the variety of your disposition one moment MILLAMANT

To hear you tell me that Foible's married, and your plot like to speed? No. 
MIRABELL

But how came you to know it -

MILLAMANT

Unless by the help of the devil, you can't imagine[.. $]^{(30)}$

This is worth quoting at length because it is striking to note how similar it is to Susan and David's as well as Godfrey and Irene's exchanges in Bringing Up Baby and My Man Godfrey respectively. Millamant runs rings around Mirabell and, as in Bringing Up Baby where, in one scene Susan and David talk over each other concurrently, Mirabell struggles to speak about his true feelings, evoking David's entreaty 'will you please stop talking,'(31) and Godfrey's similar attempt to place his conversation with Irene on a more serious footing 'can we have an intelligent conversation for a minute?'(32). Millamant is, in other ways too, the forbearer of the screwy heroine, with her childish outbursts ('ha, ha, ha!') and her sudden, theatrical mood-changes ('Now I'll be melancholy') both adumbrating Lombard's Irene, who ranges, 'whirlwind'- like, between over-excited laughter, anger (her expostulation 'yar, yar, yar'(33) aimed at Cornelia is particularly

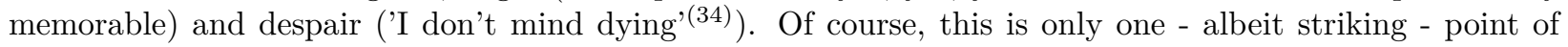
coincidence and many of the heroines of Restoration Comedy have no such quality. Alithea in The Country Wife for instance, is earnest and straightforward, in many ways opposite to Millamant, Susan and Irene.

The 'Screwball spirit' I have mentioned several times up to now, perhaps requires further definition because it is crucial to what defines Screwball Comedy and what differentiates it from Restoration Comedy. The Screwball manner can be more effectively described as the retention of childishness, a Peter Pan-esque refusal to grow up. The 'yar yar yar' of Carol Lombard cited earlier, as well as her elaborate play-acting and tantrums are not only 'screwy' and 'madcap' but the behaviour of an overgrown child. Godfrey polemically puts it:

GODFREY [to CORNELIA]

You belong to that unfortunate category that I would call the 'Park Avenue Brat', a spoiled child that's been brought up in ease and luxury and who's misdirected energies are so childish. ${ }^{(35)}$

Certainly, there is a sense that the Bullock household are a collection of 'spoiled children' running wild under the ineffective supervision of the patriarch Mr. Bullock and the butler Godfrey. In Holiday, the freewheeling spirits of both Hepburn and Grant are also childish, as they find their natural environment in a childhood den where they can perform circus tricks, bang drums, sing songs and play 'Punch and Judy'. Such behaviour appears in the films as a mark of ingenuousness, free from the stuffy, even corrupting influence of adult responsibility, most strikingly evinced in the characters of Edward Seton in Holiday and Anthony P. Kirby in You Can't Take it With You (1938). It is the most clear definition of Screwball behaviour, which even Major Horace Applegate (Charlie Ruggles) finds himself drawn into (as he will increasingly) when he enters Aunt Elizabeth's Connecticut estate and Aunt Elizabeth points out 'you're much too big to swing on gates'(36) as he attempts to clamber over a half-shut door. It is as if the house has temporarily become screwy, only to be entered through a regression to childish behaviour.

The relationship between Jean and Hopsy in The Lady Eve also seems to be defined in terms of childishness:

CHARLES / HOPSY [to JEAN]

It's like people following each other in a forest glade, only way back there you're a little girl [...] and a little boy is standing with you holding your hand. ${ }^{(37)}$

The simple image of 'a little girl' and 'a little boy' following each other and holding each others' hands is central to the relationship dynamic of most Screwball Comedy. It evokes the type of basic loving interaction of man and woman, the primal practice of pursuit and chasing as well as the equivalence of love and aggression, the 'name-calling', 'pulling pigtails' instinct which so often dictates the way humans engage with each other. As Susan notes to the psychiatrist in Bringing Up Baby:

\section{SUSAN}

What would you say about a man who follows a girl around and then when she talks with him he fights with her?

DR. FRITZ LEHMAN

The love impulse in men very frequently reveals itself in terms of conflict. ${ }^{(38)}$ 
Susan skews the truth of the matter in her summary of David's behaviour, as he follows her out of necessity rather than choice: he begrudgingly enjoys it, though it takes a good part of the film before he can bring himself to want to spend time with her. Nevertheless, the idea of the 'love impulse' in men being 'expressed in terms of conflict' is crucial, as it helps articulate the nature of so many of these Screwball and also Restoration Comedy loving relationships. The 'cult of chase'(39) as Norman N. Holland describes it, is played out again and again in Screwball Comedy and most notably in Bringing Up Baby and The Philadelphia Story, to which Salgãdo's comment, describing Restoration Comedy, could be applied:

[Restoration Comedy's] outlook on life appears to be that of the bivouac - pitch camp for the night and let joy be unconfined, for who knows what the morrow will bring? - and its strategy that of the hunt applied to the pursuit of women. ${ }^{(40)}$

The sense of tensions being resolved in a haze of Screwball activity outside the confines of a normal environment (in the acreage of their estates), along with the uncertainty of the future ('what will tomorrow bring?'), is neatly expressed here, as is the 'cult of chase' dynamic, though more often the woman chases the man in Screwball.

In Screwball, there is usually a discrepancy between who a given character should marry and who they in fact do marry and from this springs the 'conflict'. In His Girl Friday this is particularly apparent (despite the genders being reversed), as society's conception of an ideal husband (as well as his country residence with mom) cannot, despite her apparent efforts, keep Hildy from her instinctual love, the grotesque Walter Burns to whom she capitulates in one of cinema's most disturbing comic endings (their honeymoon soon becomes a business trip due to Burns's workaholism).

In The Way of the World a similar dynamic arises as Millamant loves Mirabell despite her best efforts and must grin and bear it:

\section{MILLAMANT}

Well then - I'll take my death I'm in a horrid fright - Fainall, I shall never say it - well - I think I'll endure it. ${ }^{(41)}$

The 'conflict' of ineluctable love is nowhere better expressed than this, with its hesitating dashes and the indicative volte face from 'I'll never say it' to 'I'll endure it' within the same sentence. As a further link to Screwball, this scene contains what Norman N. Holland describes as the 'Contract scene [which] shows the enchanting Millamant brought from girlhood to maturity. ${ }^{(42)}$ For Holland, this scene, in which Mirabell demands that Millamant subscribe to his specifically sexual and procreative demands, is the moment where Millamant must succumb to marriage and growing up. Millamant's helplessness in the face of her overbearing love for Mirabell is echoed in The Man of Mode (1676), in which Emilia says 'Our love is frail as is our life, and full as little in our power'(43), a maxim which explains much about Restoration Comedy's often sceptical conception of love and marriage.

The 'conflict' of the love impulse though, is expressed in many other ways in Restoration Comedy: as cuckoldom and adultery are commonplace in the plays as the characters' conflicts go unchecked and they attempt to escape their stuffy marriages. Fainall's extra-marital affair with Mrs. Marwood is discovered in the final act of The Way of the World and he responds fascinatingly:

\section{FAINALL}

If it all must come out, why, let 'em know it, 'tis but the way of the world. That shall not urge me to relinquish or abate one tittle of my terms. ${ }^{(44)}$

In one of only a few uses of the play's title in the text Fainall creates a dark view of a world where adultery is normative and love is dead. This view is supported by the entire corpus of Restoration Comedy, as cuckoldom and adultery abound and marriage is continually undermined. One can bask in the hope that characters such as Mirabell and Millamant, united through the more fundamental love / aggression impulse, will have a fulfilling marriage. Yet, there is a profusion of failed marriages or purely commercial marriages which weigh against it heavily, as do the numerous unions in extempore due to a servant's indiscretion. The glimpses of wedded life are also far from encouraging, as characters frequently bemoan what they see as imprisonment and react by committing adultery: 


\section{BEN}

A man that is married, d'ye see, is no more like another man than a galley-slave is like one of us

free sailors. He is chained to an oar all his life, and mayhap forced to tug a leaky vessel. ${ }^{(45)}$

This is typical and provides a familiar image of wedlock as bondage, with little hope of escape in a culture where divorce was frowned upon. As Dorimant professes in The Man of Mode: 'Love gilds us over, and makes us show fine things to one another for a time, but soon the gold wears off and then again the native brass appears.' ${ }^{(46)}$ When one sets this against the incipient marriages of Mirabell and Millamant or Harcourt and Alithea, then no matter what 'fine things' they create in courtship, no matter how passionate their confrontations are, this pessimistic image of marriage overshadows them.

Screwball is far more upbeat, working as a confirmation of marriage rather than a sceptical critique of it. The essence of remarriage is confirmatory, suggesting that there is and always will be one 'true love' which will endure despite divorce, argument or rupture, things which only seem to make the relationship stronger (as in the opening sequence of Mr. $\mathcal{G}$ Mrs. Smith). By attempting to divorce, the lovers simply marry again with twice the assurance, having tested the alternative. Marriage is a force for ultimate good in Screwball Comedy and well it might be, without the spectre of arranged marriages and monetary or inheritance issues, it works as a more secure system, able to function ideally in twentieth century America's liberal society. Adam's Rib presents middle-aged married life in stark opposition to the image provided by Dorimant and Ben earlier, as Katharine Hepburn and Spencer Tracey enjoy something of a perfect union. They are able to have blistering arguments and make up, they hit each other and massage each other, but crucial to all this, they are able to maintain an equal footing, giving tit for tat and each fighting their corner vociferously. They manage to retain the childish spirit so crucial to Screwball, as they poke their tongues at each other, make faces under a bench in a court room and give each other the nickname 'pinky'.

Colly Cibber creates an ostensibly confirmatory remarriage in his Love's Last Shift:

\section{LOVELESS}

Have I not used thee like a Villain? For almost ten long Years depriv'd thee of my Love, and ruin'd all thy Fortune! But I will labour, dig, beg, or starve to give new Proofs of my unfeign'd Affection. ${ }^{(47)}$

This is an apposite example of the new sentimentalist approach instituted by Cibber and this play was an integral part of the style's conception. Yet because it is so sentimental, it begins to be unbelievable (Cibber perhaps knew this) and, as David Womersly points out in his introduction to Vanbrugh's The Relapse (1696, itself written as a riposte to Cibber's perceived sentimentalism) 'Cibber's play is more equivocal than at first glance it might seem'(48). Because it is so neat and extreme a turnaround, one is invited to be sceptical of Loveless, whose conduct is amply described by Snap at the beginning of the play:

\section{SNAP}

In the first you marry'd, and grew weary of your Wife: In the second you whor'd, drank, gam'd run in Debt, mortgaged your Estate, and was forc'd to leave the Kingdom. ${ }^{49)}$

As Snap mounts up his list of charges against Loveless (which runs onto several more lines outside of this excerpt) one is tempted to remember it when Loveless professes redemption. It depends on the amount of faith an audience would have, but Cibber's play is crafted in order to invite scepticism and - the more for seeming to endorse it - further undermine the Restoration perception of marriage.

Many of these themes I have explored cohere and stem from the topos of the inner and the outer human, which has been a fascination of writers throughout English history. The fop, for instance, is a figure of fun precisely because he embodies the affected quality of so many in the beau monde, Carolean upper-echelons. Screwball Comedy is full of impersonation (Katharine Hepburn's 'Swingin' Door Suzie' act in Bringing Up Baby is notable) and playacting, while Restoration Comedy has eavesdropping and cross-dressing, as notions of identity, nature and superficiality are examined. Even the ingenuousness of childhood, which in many ways comprises Screwball behaviour, is a peeling away of social layers in order to reach the essence of the characters.

The intellectual texture of the age was configured by the Cartesian maxim that 'Nature can be defined 
through numbers' and Thomas Hobbes's political philosophy, both of which helped sustain the focus of writers on what is scientifically ascertainable and what the true nature of things are. Derek Hughes makes this link clearer in his essay 'Restoration and Settlement: 1660 and 1688':

Like many other dramatists of his generation, Dryden has a keen, if critical, interest in the materialistic philosophy of Thomas Hobbes. For Hobbes [...] man was matter in motion, driven by bodily appetites and aversions, his reason a tool of his desires. Because of man's appetitive nature, his natural relationship to his fellows, in a state prior to society, is that of war [...] In forming political societies, humanity erects defences against the horror of its own aggressive and antisocial nature[.] ${ }^{(50)}$

Hughes demonstrates the ways in which Hobbes's exploration of man's natural instincts and tendencies helped encourage Restoration dramatists' fixation with the inside and outside. A residue of this 'natural state of war' survives in the characters' social interaction, as many of the characters' relationships are defined in terms of conflict and verbal combat, not least those of the innamorati. It touches upon the idea (mentioned earlier) that the love impulse is expressed in terms of conflict and the suggestion is, that no matter how much affectation one covers over a human's basic instincts, they will surface. The romantic relationship dynamics in both Restoration Comedy and Screwball Comedy fall along these ideas of inner and outer, as they are written in such a way that what is expressed outwardly is opposite to what is felt inwardly:

TATTLE

De'e think you can love me?

MISS PRUE

Yes.

TATTLE

Pooh, pox, you must not say yes already. I shan't care a farthing for you then in a twinkling.

MISS PRUE

What must I say then?

TATTLE

Why you must say no, or you believe not, or you can't tell.

MISS PRUE

Why, must I tell a lie then?

TATTLE

Yes, if you would be well-bred. All well-bred persons lie. Besides, you are a woman, you must never speak what you think. Your word must contradict your thoughts, but your actions may contradict your words. ${ }^{(51)}$

In this amusing exchange Congreve formulates the conventionality of courtship, uncovering the tacit rules of the game and discovering how absurd they are. It is a ritual and an act, of particular interest to someone like Congreve with his metatheatrical focus. Similarly, Carol Lombard's act 'number 8 at drama school' as identified by Cornelia in My Man Godfrey, in which she swoons winsomely, is appropriate for what she perhaps rightly sees as the game of love.

Pauline Kael's hasty comment does hold some superficial merit and there are points of similarity thematically, stylistically and structurally in the bodies of work under consideration. However, such a parallel is doomed to be inaccurate, as it demands the comparison of irreconcilable genres. No matter how many coincidences one is able to find in these works, their historical, geographical and cultural differences are too great to breach. Perhaps, as Cavell seeks to argue, one should turn to Shakespeare and Ibsen to find a worthwhile investigation, but these seem to be equally fruitless as the same attempt to fuse together two radically different works can only be fraught with difficulty. In this case, the madcap spirit of Screwball and the lascivious satire of Restoration Comedy, their most definitive features, could not find their equivalents in each other in anything beyond occasional chiming. 


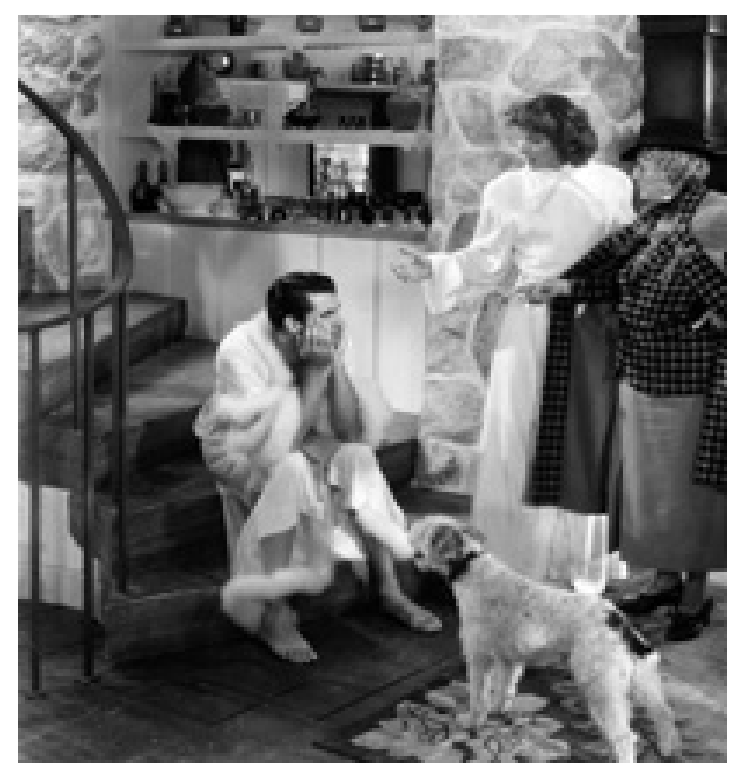

Figure 1: Bringing Up Baby (1938) by Howard Hawks

\section{Notes}

1. Pauline Kael, 5001 Nights at the Movies (1982), foreword by William Shawn (London, 1983), p. vii. NM hereafter.

2. Will Brantley ed., Conversations with Pauline Kael (Jackson, 1996), p. 8.

3. Deborah Payne Fisk ed., The Cambridge Companion to Restoration Theatre (Cambridge, 2005), 'Comedy' by Brian Corman, p. 65. $C C$ hereafter.

4. NM, p. 379 .

5. Gãmini Salgãdo, ed., Three Restoration Comedies (Wiltshire, 1968), 'The Country Wife', 3.2, p.192. TRC hereafter.

6. Duane Byrge, Robert Milton Miller, The Screwball Comedy Films: A History and Filmography, 19341942', foreward by Arthur Knight (Chicago, 1991), p.2.

7. Stanley Cavell, Pursuits of Happiness: The Hollywood Comedy of Remarriage (Cambridge, Mass., 1981) p.2.

8. Peter Holland, The Ornament of Action (Cambridge, 1979), p.x.

9. $C C$, 'The Performance', p.20.

10. Ibid., 'The Performance', p.33.

11. TRC, 'The Country Wife', 4.2, p.215.

12. Ibid., 'The Country Wife', IV.iv, p.232.

13. Edward K. Sikov, Screwball: Hollywood's Madcap Romantic Comedies, foreword by Molly Haskell (New 
York, 1989), p.22.

14. TRC, 'Love for Love', 1.1, p.274.

15. Ibid., 'The Country Wife', 4.3, p.224.

16. Ibid., 'The Country Wife', 4.3, p.222.

17. $C C$, 'Comedy', p.53.

18. TRC, 'The Country Wife', 1.1, pp.161-2.

19. Ibid., 'Introduction', p.17.

20. Ibid., 'The Country Wife', 1.1, p.162.

21. Ibid., 'The Country Wife', 5.4, p.255.

22. Gregory La Cava, dir., My Man Godfrey (Universal, 1936). $M M G$ hereafter.

23. Ibid.

24. Howard Hawks, Bringing Up Baby (RKO, 1938). BUB hereafter.

25. Ibid.

26. Ibid.

27. $M M G$.

28. Ibid.

29. William Congreve, The Way of the World, ed. Brian Gibbons (London, 1994). 2.1, p.48. WWW 
hereafter.

30. Ibid., 2.1, p.47.

31. BUB.

32. $M M G$.

33. Ibid.

34. Ibid.

35. $M M G$.

36. BUB.

37. Preston Sturges, writ. and dir., The Lady Eve (Paramount 1941).

38. $B U B$.

39. Norman N. Holland, The First Modern Comedies (Cambridge, Mass., 1959), p.185. FMC hereafter.

40. TRC, 'Introduction', p.12.

41. $W W W, 4.1$, p.84.

42. FMC, p.185.

43. TRC, 'The Man of Mode', 2.1, p.65.

44. $W W W, 5.1$, pp.113-14.

45. TRC, 'Love for Love', 3.1, p.312.

46. Ibid., 'The Man of Mode', 2.2, pp.74-75.

47. David Womersly, ed., Restoration Drama, An Anthology (Cornwall, 2000), 'Love's Last Shift', 5.3, p.588.

48. Ibid., p.596.

49. Ibid., 'Love's Last Shift', 1.1, p.556.

50. $C C$, 'Restoration and Settlement: 1660 and 1688', p.130.

51. TRC, 'Love for Love', 2.2, p.302.

\section{References}

\section{Abbreviations used}

$B U B=$ Bringing Up Baby.

$C C=$ The Cambridge Companion to Restoration Theatre.

$F M C=$ The First Modern Comedies.

$M M G=$ My Man Godfrey.

$N M=5001$ Nights at the Movies.

TRC $=$ Three Restoration Comedies: Etherege/The Man of Mode, Wycherley/The Country Wife, Congreve/Love for Love.

$W W W=$ The Way of the World.

\section{Bibliography}

Brantley, Will ed., Conversations with Pauline Kael (Jackson, 1996).

Byrge, Duane, Miller, Robert Milton, The Screwball Comedy Films: A History and Filmography, 1934-1942', foreword by Arthur Knight (Chicago, 1991).

Cavell, Stanley, Pursuits of Happiness: The Hollywood Comedy of Remarriage (Cambridge, Mass., 1981). 
Congreve, William, The Way of the World, ed. Brian Gibbons (London, 1994).

Fisk, Deborah Payne ed., The Cambridge Companion to Restoration Theatre (Cambridge, 2000).

Holland, Norman N., The First Modern Comedies: the significance of Etherege, Wycherley, and Congreve (Cambridge, Mass., 1959).

Holland, Peter, The Ornament of Action (Cambridge, 1979).

Kael, Pauline, 5001 Nights at the Movies, foreword by William Shawn (London, 1983).

Nicoll, Allardyce, A History of Restoration Drama, 1660 - 1700 (Cambridge, 1923).

Salgdo, Gmini ed., Three Restoration Comedies: Etherege/The Man of Mode, Wycherley/The Country Wife, Congreve/Love for Love (Wiltshire, 1968).

Sikov, Edward K., Screwball: Hollywood's Madcap Romantic Comedies, foreword by Molly Haskell (New York, 1989).

Womersly, David ed., Restoration Drama, An Anthology (Cornwall, 2000).

\section{Filmography}

Capra, Frank dir., It happened One Night (Columbia, 1934).

Cukor, George dir., Adam's Rib (MGM, 1949).

Cukor, George dir., Holiday (Columbia, 1940).

Cukor, George dir., The Philadelphia Story (MGM, 1940).

Hawks, Howard dir., Bringing Up Baby (RKO, 1938).

Hawks, Howard dir., His Girl Friday (Columbia, 1940).

Hitchcock, Alfred dir., Mr and Mrs Smith (RKO, 1941).

Kanin, Garson dir., My Favourite Wife (RKO, 1940).

La Cava, Gregory dir., My Man Godfrey (Universal, 1936).

McCarey, Leo dir., The Awful Truth (Columbia, 1937).

Sturges, Preston writ., prod. and dir., Hail The Conquering Hero (Paramount 1941).

Sturges, Preston writ. and dir., The Lady Eve (Paramount 1941).

Sturges, Preston dir., The Palm Beach Story (Paramount, 1942).

Sturges, Preston, dir., Sullivan's Travels (Paramount, 1941).

Wellman, William A. dir., Nothing Sacred (Selznick International, 1937).

\section{Internet}

The All Movie Guide (www.allmovie.com).

Wikipedia (en.wikipedia.org).

The Internet Movie Database (www.imdb.com).

\section{Author Information}

Oliver TILLEY graduated with a BA degree in English Literature from the University of Cambridge. He is pursuing graduate programme in Film Studies at the University College London. 